\title{
Synthesis and Cytotoxicity of Thieno[2,3-b]Pyridine Derivatives Toward Sensitive and Multidrug-Resistant Leukemia Cells
}

\author{
Salah A. Al-Trawneh, ${ }^{1, \star}$ Amer H. Tarawneh, ${ }^{2}$ Anastassiya V. Gadetskaya, ${ }^{3}$ \\ Ean-Jeong Seo, ${ }^{4}$ Mohammad R. Al-Ta'ani, ${ }^{1}$ Samir A. Al-Taweel ${ }^{1}$ \\ and Mustafa M. El-Abadelah ${ }^{5}$ \\ ${ }^{1}$ Chemistry Department, Faculty of Science, Mu'tah University, Karak 61710, Jordan \\ ${ }^{2}$ Chemistry and Chemical Technology Department, Faculty of Science, Tafila Technical University, Tafila 61610, Jordan \\ ${ }^{3}$ School of Chemistry and Chemical Technology, Al-Farabi Kazakh National University, Almaty 050040, Kazakhstan \\ ${ }^{4}$ Department of Pharmaceutical Biology, Institute of Pharmaceutical and Biomedical Sciences, Johannes Gutenberg \\ University, Staudinger Weg 5, 55128 Mainz, Germany \\ ${ }^{5}$ Chemistry Department, Faculty of Science, The University of Jordan, Amman 11942, Jordan \\ *Corresponding author: E-mail: laratr@mutah.edu.jo \\ Phone: $+96232372380 / 4561$
}

Received: $12-17-2020$

\begin{abstract}
A new series of substituted ethyl 7-cyclopropyl-2-(2-aryloxo)-3-nitro-4-oxo-4,7-dihydrothieno[2,3-b]pyridine-5-carboxylates 3a-e were prepared by utilizing ethyl 2-chloro-7-cyclopropyl-3-nitro-4-oxo-4,7-dihydrothieno[2,3-b]pyridine-5-carboxylate (1) and replacing of the 2-chlorine with anions obtained from phenol (2a), salicylaldehyde derivatives $\mathbf{2 b}-\mathbf{d}$ or thiophenol (2e), leading to the respective ethyl 7-cyclopropyl-2-(2-aryloxo)-3-nitro-4-oxo-4,7-dihydrothieno[2,3-b]pyridine-5-carboxylates 3a-e. The new compounds were evaluated for their in vitro cytotoxicity towards sensitive CCRF-CEM and multidrug-resistant CEM/ADR5000 leukemia cells. The screening revealed that compounds $\mathbf{3 a}, \mathbf{3 b}$, and $\mathbf{3 e}$ inhibited the growth of both cell lines. Compound $\mathbf{3 b}$, with a phenol moiety, exhibited the highest growth inhibitory activity against CEM/ADR5000 and CCRF-CEM cells with IC $_{50}$ values $4.486 \pm 0.286$ and $2.580 \pm 0.550 \mu \mathrm{M}$, respectively. Collectively, the presented results demonstrate that the synthesized thieno[2,3-b]pyridines warrant further exploration for potential use as anti-cancer agents.
\end{abstract}

Keywords: Thieno[2,3-b]pyridine, Multidrug resistance, Cytotoxicity.

\section{Introduction}

Thieno $[2,3-b]$ pyridines were mentioned for the first time in $1913 .{ }^{1}$ The chemistry of thieno[2,3-b] pyridines has been well documented during the past decades. ${ }^{1}$ Various biological activities of this heterocyclic compounds class were described, ${ }^{2}$ such as antimicrobial, ${ }^{3-6}$ anti-inflammatory, ${ }^{7-9}$ antioxidant, ${ }^{6}$ antituberculosis, ${ }^{4}$ and antimalarial activities. ${ }^{10}$ Moreover, the incorporation of the $N$-cyclopropyl group with 4-oxothieno[2,3-b] pyridines showed a higher potency against Escherichia coli ATCC10536 than the $N$-ethyl and $N$-tert-butyl analogs. ${ }^{11}$ It is important to mention that compounds containing thieno[2,3-b]-pyridines moieties attracted considerable interest regarding their potency as anti-cancer agents. ${ }^{12-14}$

Despite severe undesired side effects, chemotherapeutics are considered effective treatments of primary and metastatic tumors (Figure 1). ${ }^{15}$

One serious problem of cancer chemotherapy is the development of resistance towards multiple structurally and functionally unrelated anti-cancer drugs. ${ }^{16-18}$ This phenomenon defined as multidrug resistance (MDR), where chemotherapy fails even at high drug, which leads to toxic side effects. ${ }^{19} \mathrm{MDR}$ is frequently caused by the 
<smiles>COc1cccc2c1C(=O)c1c(O)c3c(c(O)c1C2=O)C[C@@](O)(C(=O)CO)C[C@@H]3O[C@H]1C[C@H](N)[C@H](O)[C@H](C)O1</smiles>

doxorubicin<smiles>COc1cccc2c1C(=O)c1c(O)c3c(c(O)c1C2=O)C[C@@](O)(C(=O)CO)C[C@@H]3O[C@H]1C[C@@H](N)[C@H](O)[C@H](C)O1</smiles>

epirubicin

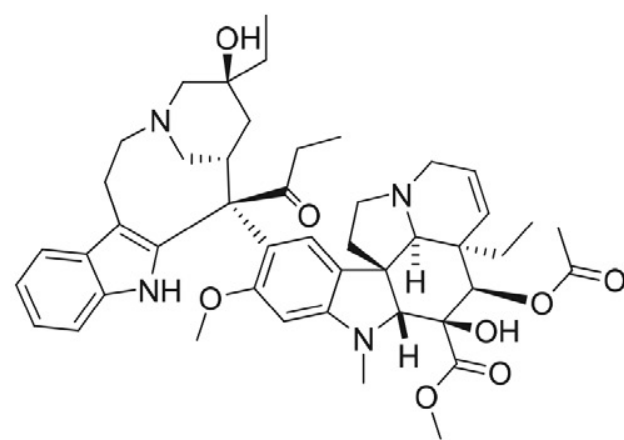

vinblastine

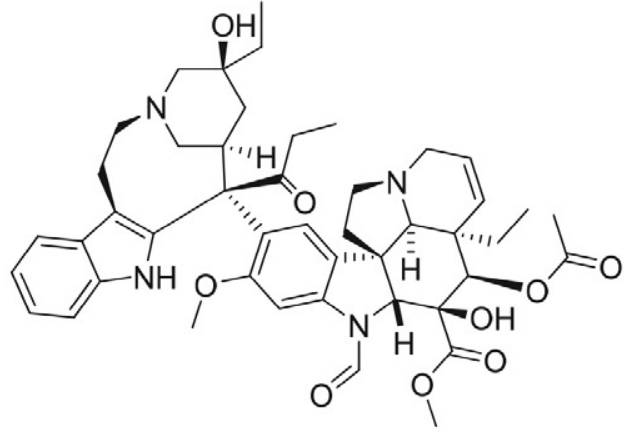

vincristine<smiles>COc1cc([C@H]2c3cc4c(cc3[C@@H](O[C@@H]3O[C@H]5CO[C@H](C)O[C@H]5[C@H](O)[C@H]3O)[C@]3(C)COC(=O)C23)OCO4)cc(OC)c1O</smiles>

etoposide<smiles>Cc1ccc(NC(=O)c2ccc(CN3CCN(C)CC3)cc2)cc1Nc1nccc(-c2cccnc2)n1</smiles>

imatinib

Figure 1. Representative samples of chemotherapy in market.

overexpression of membrane efflux pumps of the ATPbinding cassette $(\mathrm{ABC})$ transporter family. The best characterized ABC-transporter in this context is P-glycoprotein (Pgp), which causes increased transport of chemotherapeutic agents out of the cells. ${ }^{20,21}$

Thieno[2,3-b]pyridines have been reported to exhibit chemopreventive effects suppressing carcinogenesis of numerous tumor types including breast, prostate, non-small cell lung, melanoma, leukemia, ovarian, liver, and colon cancer. ${ }^{22,23}$ As a part of our continuing search for novel biological agents, ${ }^{24-27}$ newly synthesized 4,7-dihydrothieno[2,3-b]pyridine derivatives were evaluated for their growth inhibitory activity towards multidrug-resistant CEM/ADR5000 cells in comparison to their pa-

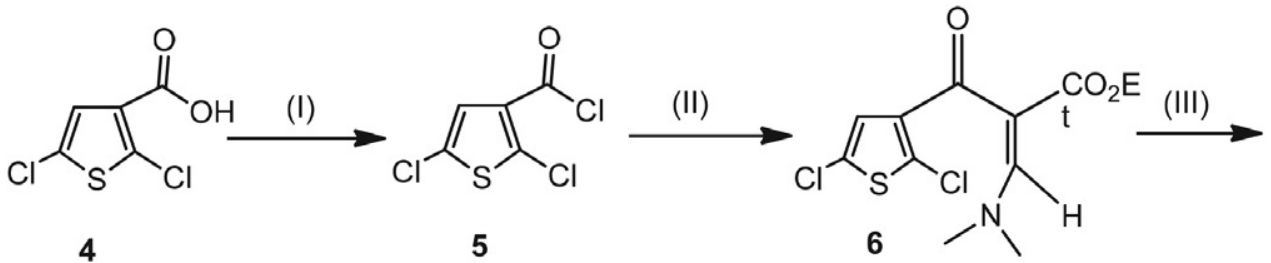<smiles>CCOC(=O)c1cn(C2CC2)c2sc(Cl)c([N+](=O)[O-])c2c1=O</smiles>

(I) $\mathrm{SOCl}_{2}$, benzene / reflux

(IV) $\mathrm{NaH} / \mathrm{THF}$

(II) $\left(\mathrm{EtO}_{2} \mathrm{C}\right) \mathrm{HC}=\mathrm{CHN}(\mathrm{Me})_{2}$, benzene, $\mathrm{NEt}_{3}$

(V) fuming $\mathrm{HNO}_{3} /$ conc $\mathrm{H}_{2} \mathrm{SO}_{4}$

(III) cyclopropylamine, dichloromethane

Scheme 1. Preparation of ethyl 3-nitro-4-oxothieno[2,3-b]pyridine-5-carboxylate 1. 
rental sensitive cell line, CCRF-CEM. This is the first report on the cytotoxicity of 4,7-dihydrothieno[2,3-b] pyridine against sensitive and multidrug resistance leukemia cells. Moreover, the structure-activity relationship of the synthesized set was also studied.

\section{Results and Discussion}

\section{1. Chemistry}

The synthesis of a selected set of 4,7-dihydrothieno[2,3-b]pyridine derivatives $\mathbf{3 a}-\mathbf{e}$ has been accomplished in two-step reactions as illustrated in Schemes 1 and 2. The first step involves the formation of ethyl 3-nitro-4-oxothieno[2,3-b]pyridine-5-carboxylate $\mathbf{1}$. The latter synthon was prepared by starting with 2,5-dichlorothiophene3-carboxylic acid (4). The following successive steps were performed according to a reported procedure. ${ }^{11}$

Freshly prepared oxyanions from phenol (2a), salicylaldehyde (2b), 5-methylsalicylaldehyde (2c), and 5-chlorosalicylaldehyde (2d) took part in subsequent nucleophilic aromatic substitution $\left(\mathrm{S}_{\mathrm{N}} \mathrm{Ar}\right)$ reactions of chloro substituent in compound $\mathbf{1}$ as shown in Scheme 2. Whereas, compound $3 \mathbf{e}$ was prepared according to the same procedure by sulfur anion obtained from benzenethiol (2e) and then reacted with compound $\mathbf{1}$ in the same manner as phenol derivatives (see Scheme 2).

The new compounds $\mathbf{1}$ and $\mathbf{3 a}-\mathbf{e}$ were characterized by IR, MS, and NMR spectral data. These data, given in the

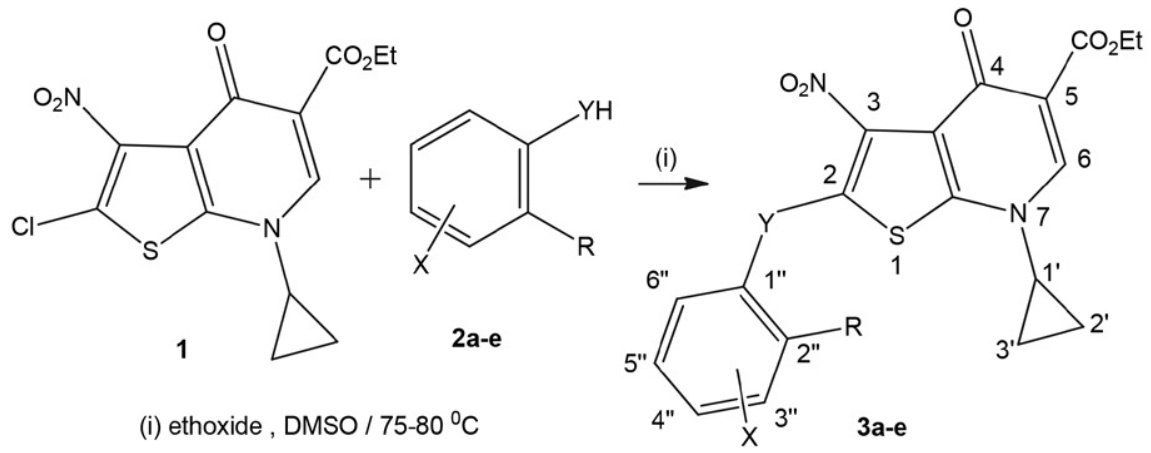

\begin{tabular}{|c|c|c|c|c|c|}
\hline compound & $\mathbf{a}$ & $\mathbf{b}$ & $\mathbf{c}$ & $\mathbf{d}$ & $\mathbf{e}$ \\
\hline $\mathrm{R}$ & $\mathrm{H}$ & $\mathrm{CHO}$ & $\mathrm{CHO}$ & $\mathrm{CHO}$ & $\mathrm{H}$ \\
\hline $\mathrm{X}$ & $\mathrm{H}$ & $\mathrm{H}$ & $4^{\prime \prime}-\mathrm{Me}$ & $4^{\prime \prime}-\mathrm{Cl}$ & $\mathrm{H}$ \\
\hline $\mathrm{Y}$ & $\circ$ & $\circ$ & $\circ$ & $\circ$ & $S$ \\
\hline
\end{tabular}

Scheme 2. Synthesis of ethyl 2-(aryloxo)-7-cyclopropyl-3-nitro-4-oxo-4,7-dihydrothieno[2,3-b]pyridine-5-carboxylic acids 3a-e.

Table 1. NMR spectroscopic data $\left(500 \mathrm{MHz}, \mathrm{CDCl}_{3}\right)$ for compound 3a.

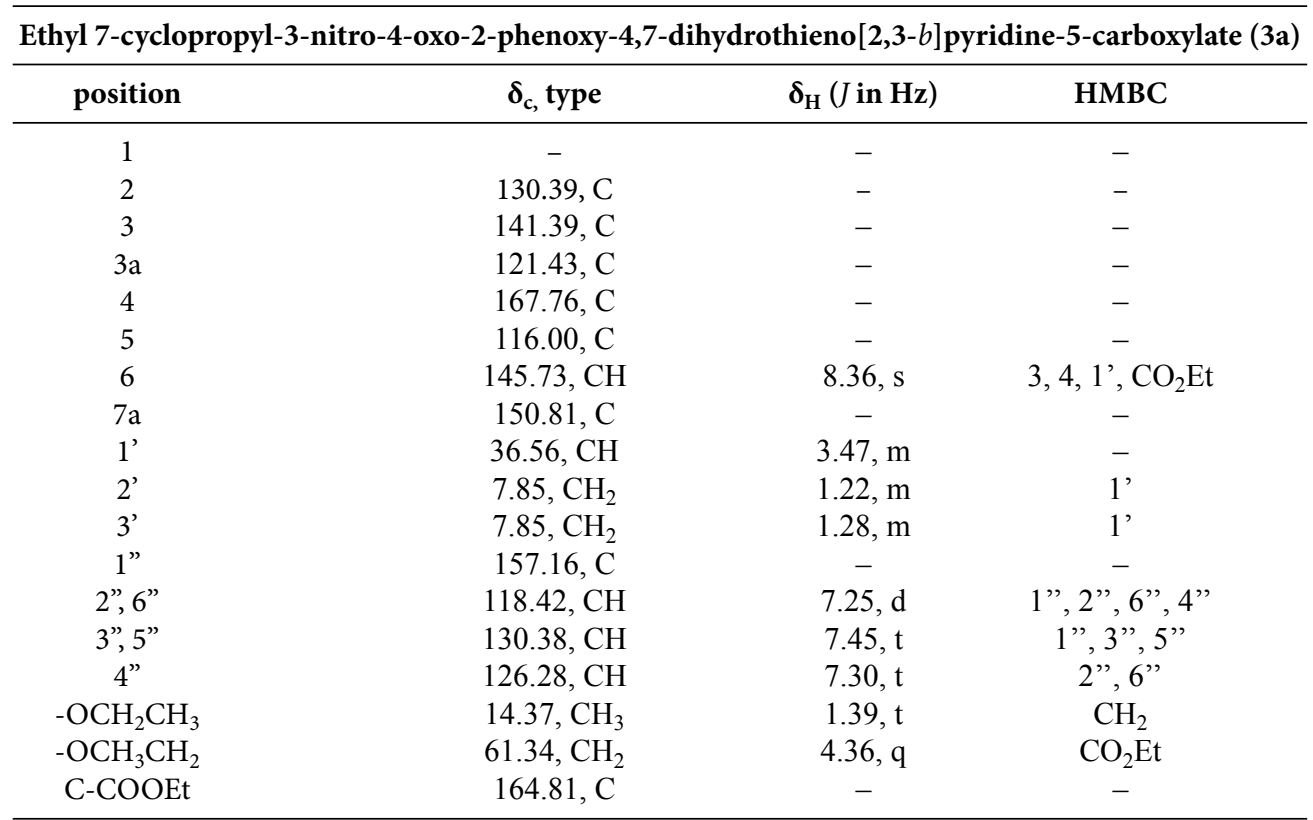


experimental section, were in compliance with the assigned structures. HMBC correlations allowed the complete assignments: the protons at position $\mathrm{H}-5$ " showed a common strong correlation in all compounds $\mathbf{3 a}-\mathbf{e}$ with the carbons at positions C-1", C-3" and a weak one with the carbons at positions C-4" and C-6", while in compound 3c an additional correlation of the protons at $\delta_{\mathrm{H}} 7.54(\mathrm{~d}, J=$ $8.0 \mathrm{~Hz}, 1 \mathrm{H}, \mathrm{H}-5$ ") with the carbons of the methyl group at $\delta_{\mathrm{C}} 20.69\left(\mathrm{C}-\mathrm{CH}_{3}\right)$ was observed. The presence of the aldehyde group at position C-2" enabled to differentiate the correlation in compounds $\mathbf{3 b}-\mathbf{d}$ for the protons at position $\mathrm{H}-3$ " which showed a correlation with the carbons at positions C-1", C-5" and with the aldehyde carbon itself at $\delta_{\mathrm{C}}$ 186.22-188.9 (C-CHO). In addition, in compound $3 \mathrm{c}$ the correlation between the signal at $\delta_{\mathrm{H}} 7.84(\mathrm{~s}, 1 \mathrm{H}, \mathrm{H}-3$ ") $)$ and the signal at $\delta_{\mathrm{C}} 20.69\left(\mathrm{C}-\mathrm{CH}_{3}\right)$ for the methyl group was detected. The correlation of proton at position $\mathrm{H}-4$ " with the carbons at positions C-2" and C-6" was presented in all compounds, except for compounds $\mathbf{3 c}-\mathbf{d}$ due to substituted position C-4" to methyl and chloro, respectively. The NMR data of the compound $\mathbf{3 a}$, as a representative of the title compounds $3 \mathbf{a}-\mathbf{e}$, are shown in Table 1.

Thus, the mass spectra display the correct molecular ion peaks, for which the measured high-resolution mass spectra (HRMS) data were in good agreement with the calculated values. DEPT and 2D (COSY, HMQC, HMBC) experiments showed correlations that helped in the ${ }^{1} \mathrm{H}$ and ${ }^{13} \mathrm{C}$ signal assignments to the different carbons, and they are attached and/or neighboring hydrogens. H-6 proton resonating at 8.36 as a sharp singlet made a long-range correlation with C-3, C-4, C-1' and $\mathrm{CO}_{2}$ Et. In addition, protons 2', 3' show correlation with C-1'. On the other hand, the phenol ring correlated with aldehyde functionality (Table 1).

\section{2. Biological Evaluation. Cytotoxic Activities Against Lymphoblastic Leukemia Cells}

As the first step, all compounds were tested at a fixed concentration of $10 \mu \mathrm{M}$ (Figure 2) in CCRF-CEM and CEM/ADR5000 cells. Compounds $\mathbf{3 a}$, $\mathbf{3 e}$, and $\mathbf{3 b}$ significantly inhibited cell viability (reduction to less than $10 \%$ growth).

From the structure-activity relationship (SAR) point of view, incorporating salicylaldehyde moiety to thieno[2,3-b]pyridine (3b) exhibited good activity against CCRF-CEM and CEM/ADR5000 cells with $\mathrm{IC}_{50}$ values of 4.76 and $5.11 \mu \mathrm{M}$, respectively. However, incorporating the phenol moiety (3a) increased activity against CCRF-CEM and CEM/ADR5000 (Table 2). Changing the hydrogen on the para position of $\mathbf{3 b}$ with a halogen in $\mathbf{3 d}$ or with methyl in $3 \mathrm{c}$ led to reduced biological activity against both cell lines. While replacement of the phenol moiety with thiophenol in $\mathbf{3 e}$ retrieved biological activity against CCRF-CEM and CEM/ADR5000 cells with $\mathrm{IC}_{50}$

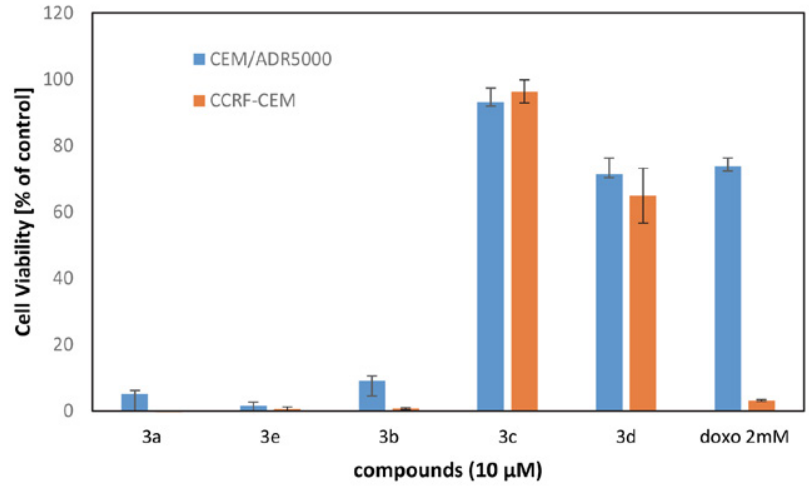

Figure 2. Growth percentage (\%) of drug-sensitive lymphoblastic leukemia CCRF-CEM cells and multidrug-resistant P-glycoprotein-overexpressing subline CEM/ADR5000 cells treated with compounds 3a-e at a concentration of $10 \mu \mathrm{M}$. Doxorubicin (doxo) was used as control. Results of three independent experiments with every six parallel measurements are shown.

values of 4.00 and $4.59 \mu \mathrm{M}$ for $3 \mathbf{e}$, respectively (Table 2). This is a remarkable result since CEM/ADR cells are more than 1000-fold resistant to the established anti-cancer drug doxorubicin. ${ }^{28}$ Hence, these compounds inhibited multidrug-resistant cells with similar efficacy as sensitive cells, possibly qualifying them as candidates for further development as treatment of unresponsive cancers.

Table 2. Cytotoxicity of active compounds towards sensitive human lymphoblastic CCRF-CEM and multidrug-resistant CEM/ ADR5000 leukemia cells as determined by the resazurin assay.

\begin{tabular}{lccc}
\hline $\begin{array}{l}\text { Com- } \\
\text { pounds }\end{array}$ & $\begin{array}{c}\text { CCRF- } \\
\text { CEM }\end{array}$ & $\begin{array}{c}\mathrm{IC}_{50}[\mu \mathrm{M}]^{\mathrm{a}} \\
\text { CEM/ } \\
\text { ADR5000 }\end{array}$ & $\begin{array}{c}\text { Degree of } \\
\text { resistance }\end{array}$ \\
\hline 3a & $2.580 \pm 0.550$ & $4.486 \pm 0.286$ & 1.74 \\
3b & $4.763 \pm 0.160$ & $5.109 \pm 0.294$ & 1.07 \\
3e & $4.009 \pm 0.154$ & $4.591 \pm 0.017$ & 1.15 \\
\hline
\end{tabular}

a The lymphoblastic leukemia cells were treated with different concentrations of each compound. Mean values and standard deviation of three independent experiments with every six parallel measurements are shown. ${ }^{\mathrm{b}}$ The degrees for resistance were calculated by division of the $\mathrm{IC}_{50}$ values of the compounds for CEM/ADR5000 by the corresponding $\mathrm{IC}_{50}$ values for CCRF-CEM cells.

\section{Experimental}

\section{1. Chemicals and Equipment}

2,5-Dichlorothiophene, cyclopropylamine, 3-acetyl-2,5-dichlorothiophene, phenol, 2-hydroxybenzaldehyde, 2-hydroxy-5-methylbenzaldehyde, 5-chloro-2-hydroxybenzaldehyde, and thiophenol were purchased from Aldrich. Sodium hydride, sodium hydroxide, magnesium sulfate, triethylamine, dimethylformamide, dimethyl sulfoxide, thionyl chloride $\left(\mathrm{SOCl}_{2}\right)$, and ethyl 3-(N,N-dimethylamino)acrylate were purchased from Acros. Benze- 
ne and tetrahydrofuran were dried over sodium metal and distilled, then collected under the nitrogen atmosphere. Thin-layer chromatography plates (Macherey-Nagel GmbH \& Co.KG Xtra-SIL G/UV254, $20 \times 20 \mathrm{~cm}, 0.20 \mathrm{~mm}$ silica gel 60). Silica gel $60,0.06-0.2 \mathrm{~mm}$ (70-230 mesh ASTM) for column chromatography. Ultraviolet Fluorescence Analysis Cabinet was used to visualize the colorless spots. Melting points (uncorrected) were determined on the Electrothermal IA6304 Melting Point apparatus in open capillary tubes. ${ }^{1} \mathrm{H}$ and ${ }^{13} \mathrm{C}$ NMR spectra were recorded on a $500 \mathrm{MHz}$ (Bruker $500 \mathrm{MHz}$ Avance III) and 400 $\mathrm{MHz}$ (Bruker Avance III $400 \mathrm{MHz}$ ) spectrometers with TMS as the internal standard. High-resolution mass spectra (HRMS) were measured (in positive or negative ion mode) using the electrospray ion trap (ESI) technique by collision-induced dissociation on a Bruker APEX-IV (7 Tesla) instrument. IR spectra were recorded on a Nicolet Impact 400 FT-IR spectrophotometer.

\section{2. Synthesis of Ethyl 2-Chloro-7- cyclopropyl-3-nitro-4-oxo-4,7- dihydrothieno $[2,3-b]$ pyridine-5- carboxylate (1)}

A mixture of 2,5-dichlorothiophene-3-carboxylic acid $4(5 \mathrm{~g}, 25.4 \mathrm{mmol})$, and thionyl chloride $\left(\mathrm{SOCl}_{2}\right)(12.0$ g, $101 \mathrm{mmol})$ were dissolved in dry benzene $(60 \mathrm{~mL})$, then refluxed for $4-5 \mathrm{~h}$ under anhydrous conditions. The solvent and excess thionyl chloride were distilled under reduced pressure, dry benzene $(20 \mathrm{~mL})$ was then added to remove the trace of thionyl chloride, and re-distilled. The resulting 2,5-dichloro-3-thionobenzoyl chloride $\mathbf{5}$ was used for the next step without further purification. To a stirred and cooled $\left(5-10^{\circ} \mathrm{C}\right)$ solution of ethyl 3-(N,N-dimethylamino)acrylate $(4.3 \mathrm{~g}, 30 \mathrm{mmol})$ and triethylamine $(5.1 \mathrm{~g}, 51 \mathrm{mmol})$ in dry benzene $(50 \mathrm{~mL})$ was added dropwise a solution of 5 in dry benzene $(20 \mathrm{~mL})$.

The resulting mixture was refluxed at $85^{\circ} \mathrm{C}$ for $2 \mathrm{~h}$, then cooled to room temperature, and washed with water $(3 \times 2 \mathrm{~mL})$. The organic layer was separated, dried over $\mathrm{MgSO}_{4}$ and the solvent was then evaporated to dryness to obtain the desired product 6 . A stirred solution of 6 in dichloromethane $(50 \mathrm{~mL})$ was treated dropwise with cyclopropyl amine $(2.85 \mathrm{~g}, 50 \mathrm{mmol})$ at $2-4^{\circ} \mathrm{C}$. The resulting mixture was then stirred at $25^{\circ} \mathrm{C}$ for $24 \mathrm{~h}$. The solvent was evaporated and the residue was soaked with hexane to obtain a yellow precipitate product 7 . Sodium hydride $(0.8 \mathrm{~g}$, $17.5 \mathrm{mmol}, 55 \%)$ in dry THF $(60 \mathrm{~mL})$ was added to the pure 7 . The reaction mixture was stirred at room temperature for $30 \mathrm{~min}$. Then, the temperature was increased to 60 ${ }^{\circ} \mathrm{C}$ for $3 \mathrm{~h}$. The solvent was evaporated, and the residual white precipitate $\mathbf{8}$ was washed with water and dried. The product crystallized from the $\mathrm{CHCl}_{3} /$ ethanol mixture $(1: 2){ }^{11}$

Finally, the nitration of $\mathbf{8}$ was achieved by dissolving 8 in concentrated sulfuric acid $(6 \mathrm{~mL})$. The latter solution was slowly and dropwise added for $30 \mathrm{~min}$ to $-5^{\circ} \mathrm{C}$ stirred solution of fuming nitric acid $(2 \mathrm{~mL})$ and concentrated sulfuric acid $(5 \mathrm{~mL})$. The mixture was allowed to warm to $5{ }^{\circ} \mathrm{C}$ and poured into the ice bath $(50 \mathrm{~mL})$. The solid product 1 was filtered and crystallized from DMF/ethanol (1:9) [mp $180-182{ }^{\circ} \mathrm{C}$ dec., total yield $30 \%$ ]. ${ }^{1} \mathrm{H}$ NMR (500 $\left.\mathrm{MHz}, \mathrm{CDCl}_{3}\right) \delta 1.26(\mathrm{~m}, 2 \mathrm{H})$ and $1.29(\mathrm{~m}, 2 \mathrm{H})\left(\mathrm{H}_{2}-2^{\prime}+\right.$ $\left.\mathrm{H}_{2}-3^{\prime}\right)$, and $1.36\left(\mathrm{t}, J=7.1 \mathrm{~Hz}, 3 \mathrm{H}, \mathrm{CH}_{3} \mathrm{CH}_{2} \mathrm{O}-\right), 3.49$ $\left(\mathrm{m}, 1 \mathrm{H}, \mathrm{H}-1^{\prime}\right), 4.35\left(\mathrm{q}, J=7.1 \mathrm{~Hz}, 2 \mathrm{H},-\mathrm{OCH}_{2} \mathrm{CH}_{3}\right), 8.36$ (s, $1 \mathrm{H}, \mathrm{H}-6){ }^{11}$

\section{3. General Procedure for Synthesis of Ethyl 2-(Aryloxo/arylthio)-7-cyclopropyl-3- nitro-4-oxo-4,7-dihydrothieno[2,3-b] pyridine-5-carboxylates 3a-e}

To a stirred solution of $1(0.2 \mathrm{~g}, 0.6 \mathrm{mmol})$ in dimethyl sulfoxide $(2 \mathrm{~mL})$ the appropriate sodium salt of phenol (2a), salicylaldehydes $\mathbf{2 b}-\mathbf{d}$ or thiophenol (2e) $(0.9 \mathrm{mmol})$ [prepared from the reaction of compounds 2a-e $(0.9 \mathrm{mmol})$ with sodium ethoxide $(0.06 \mathrm{~g}, 0.9$ $\mathrm{mmol}$ ) in ethanol] was slowly added. The resulting mixture was then heated at $70-80{ }^{\circ} \mathrm{C}$ for $12 \mathrm{~h}$. The reaction mixture was cooled and poured onto ice-water $(20 \mathrm{~mL})$, then extracted with chloroform $(20 \mathrm{~mL})$, the organic layer washed with water $(2 \times 20 \mathrm{~mL})$ and brine $(2 \times 20$ $\mathrm{mL}$ ), dried over anhydrous sodium sulfate $\mathrm{Na}_{2} \mathrm{SO}_{4}$ and the solvent was evaporated to yield a yellow, solid substance. This crude product was purified by column chromatography using silica gel and eluting with chloroform/ethyl acetate $(1: 1, v / v)$ to give solid products (Scheme 2).

Ethyl 7-Cyclopropyl-3-nitro-4-oxo-2-phenoxy-4,7dihydrothieno $[2,3-b]$ pyridine-5-carboxylate (3a). This compound was prepared from $1(0.2 \mathrm{~g}, 0.6 \mathrm{mmol})$ and phenol (2a) $(0.10 \mathrm{~g}, 0.9 \mathrm{mmol})$ by following the general procedure and reaction conditions as described above. Reaction time $12 \mathrm{~h}$; yield $0.20 \mathrm{~g}$ (87\%), mp $260-262{ }^{\circ} \mathrm{C}$. HRMS (ESI) $m / z[\mathrm{M}+\mathrm{Na}]$ calcd for $\mathrm{C}_{19} \mathrm{H}_{16} \mathrm{~N}_{2} \mathrm{O}_{6} \mathrm{SNa}$ : 423.06213; found: 423.06182. IR 3900, 3089, 2952, 1728, $1688,1615,1559,1486,1453,1395,1344,1320,1229$, $1199,1146,1070,1044,922,875,836,800,761,694,597$, $554 \mathrm{~cm}^{-1} .{ }^{1} \mathrm{H}$ NMR $\left(500 \mathrm{MHz}, \mathrm{CDCl}_{3}\right) \delta 1.22(\mathrm{~m}, 2 \mathrm{H})$ and $1.28(\mathrm{~m}, 2 \mathrm{H})\left(\mathrm{H}_{2}-2^{\prime}+\mathrm{H}_{2}-3^{\prime}\right)$, and $1.39(\mathrm{t}, J=7.0 \mathrm{~Hz}$, $\left.3 \mathrm{H}, \mathrm{CH}_{3} \mathrm{CH}_{2} \mathrm{O}-\right), 3.47\left(\mathrm{~m}, 1 \mathrm{H}, \mathrm{H}-1^{\prime}\right), 4.36(\mathrm{q}, J=7.0 \mathrm{~Hz}$, $\left.2 \mathrm{H},-\mathrm{OCH}_{2} \mathrm{CH}_{3}\right), 7.25$ (d, $J=7.6 \mathrm{~Hz}, 2 \mathrm{H}, \mathrm{H}-2$ " + H-6"), $7.30(\mathrm{t}, J=6.8 \mathrm{~Hz}, 1 \mathrm{H}, \mathrm{H}-4 "), 7.45(\mathrm{t}, J=8.0 \mathrm{~Hz}, 2 \mathrm{H}$, $\mathrm{H}-3 "+\mathrm{H}-5$ "), 8.36 (s, $1 \mathrm{H}, \mathrm{H}-6) \cdot{ }^{13} \mathrm{C}$ NMR (125 MHz, $\left.\mathrm{CDCl}_{3}\right) \delta 7.85\left(\mathrm{C}-2^{\prime}+\mathrm{C}^{\prime}\right), 14.37\left(-\mathrm{OCH}_{2} \mathrm{CH}_{3}\right), 36.56$ $\left(\mathrm{C}-1^{\prime}\right), 61.34\left(-\mathrm{OCH}_{2} \mathrm{CH}_{3}\right), 116.00(\mathrm{C}-5), 118.42(\mathrm{C}-2$ " + C-6"), 121.43 (C-3a), 126.28 (C-4"), 130.38 (C-3" + C-5"), 130.39 (C-2), 141.39 (C-3), 145.73 (C-6), 150.81 (C-7a), 157.16 (C-1"), 164.81 (C-COOEt), 167.76 (C-4). 
Ethyl 7-Cyclopropyl-2-(2-formylphenoxy)-3-nitro-4oxo-4,7-dihydrothieno[ $[2,3-b]$ pyridine-5-carboxylate (3b). This compound was prepared from 1 (0.2 g, 0.6 $\mathrm{mmol})$ and salicylaldehyde (2b) $(0.12 \mathrm{~g}, 0.9 \mathrm{mmol})$ by following the general procedure and reaction conditions as described above. Reaction time $12 \mathrm{~h}$; yield $0.22 \mathrm{~g}$ (85\%), mp 200-202 ${ }^{\circ} \mathrm{C}$. HRMS (ESI) $m / z$ [M+Na] calcd for $\mathrm{C}_{20} \mathrm{H}_{16} \mathrm{~N}_{2} \mathrm{O}_{7} \mathrm{SNa}$ : 451.05704; found: 451.05789. IR 3853, $3745,2983,2354,1687,1620,1542,1448,1389,1335,1229$, $1030,835,780,536 \mathrm{~cm}^{-1} .{ }^{1} \mathrm{H}$ NMR (500 MHz, DMSO- $\left.d_{6}\right) \delta$ $1.05(\mathrm{~m}, 2 \mathrm{H})$ and $1.19(\mathrm{~m}, 2 \mathrm{H})\left(\mathrm{H}_{2}-2^{\prime}+\mathrm{H}_{2}-3^{\prime}\right)$, and $1.23(\mathrm{t}$, $\left.J=7.1 \mathrm{~Hz}, 3 \mathrm{H}, \mathrm{CH}_{3} \mathrm{CH}_{2} \mathrm{O}-\right), 3.64\left(\mathrm{~m}, 1 \mathrm{H}, \mathrm{H}-1^{\prime}\right), 4.18$ (q, $J=$ 7. $\left.1 \mathrm{~Hz}, 2 \mathrm{H},-\mathrm{OCH}_{2} \mathrm{CH}_{3}\right), 7.39$ (d, $J=8.3 \mathrm{~Hz}, 1 \mathrm{H}, \mathrm{H}-6$ ”), 7.46 (t, $J=7.5 \mathrm{~Hz}, 1 \mathrm{H}, \mathrm{H}-4$ "), 7.76 (t, $J=7.4 \mathrm{~Hz}, 1 \mathrm{H}, \mathrm{H}-5$ "), 7.90 (d, $J=7.1 \mathrm{~Hz}, 1 \mathrm{H}, \mathrm{H}-3$ "), 8.32 (s, 1H, H-6), 10.26 (s, $1 \mathrm{H}, \mathrm{CHO}) .{ }^{13} \mathrm{C}$ NMR $\left(125 \mathrm{MHz}, \mathrm{DMSO}-d_{6}\right) \delta 7.68\left(\mathrm{C}-2^{\prime}+\right.$ C3'), $14.65\left(-\mathrm{OCH}_{2} \mathrm{CH}_{3}\right), 37.16\left(\mathrm{C}-1^{\prime}\right), 60.83\left(-\mathrm{OCH}_{2} \mathrm{CH}_{3}\right)$, 116.06 (C-5), 118.66 (C-6”), 119.91 (C-3a), 126.48 (C-2”), 126.90 (C-4”), 130.46 (C-3"), 131.44 (C-2), 137.06 (C-5”), 143.72 (C-3), 146.15 (C-6), 149.33 (C-7a), 158.24 (C-1”), 164.39 (C-COOEt), 167.56 (C-4), 188.9 (C-CHO).

Ethyl 7-Cyclopropyl-2-(2-formyl-4-methylphenoxy)-3nitro-4-oxo-4,7-dihydrothieno $[2,3-b]$ pyridine-5-carboxylate (3c). This compound was prepared from 1 ( $0.2 \mathrm{~g}$, $0.6 \mathrm{mmol}$ ) and 2-hydroxy-5-methylbenzaldehyde (2c) $(0.14 \mathrm{~g}, 0.9 \mathrm{mmol})$ by following the general procedure and reaction conditions as described above. Reaction time 12 h; yield $0.16 \mathrm{~g}$ (62\%), mp 203-205 ${ }^{\circ} \mathrm{C}$. HRMS (ESI) $\mathrm{m} / \mathrm{z}$ [M+Na] calcd for $\mathrm{C}_{21} \mathrm{H}_{18} \mathrm{~N}_{2} \mathrm{O}_{7} \mathrm{SNa}$ : 465.07269; found: 465.07196. IR 1625, 1566, 1532, 1497, 1449, 1394, 1343, 1240, 1192, 1144, 1070, $796 \mathrm{~cm}^{-1} .{ }^{1} \mathrm{H}$ NMR $(500 \mathrm{MHz}$, $\left.\mathrm{CDCl}_{3}\right) \delta 1.30(\mathrm{~m}, 2 \mathrm{H})$ and $1.40(\mathrm{~m}, 2 \mathrm{H})\left(\mathrm{H}_{2}-2^{\prime}+\mathrm{H}_{2}-3^{\prime}\right)$, and $1.45\left(\mathrm{t}, J=7.0 \mathrm{~Hz}, 3 \mathrm{H}, \mathrm{CH}_{3} \mathrm{CH}_{2} \mathrm{O}-\right), 2.50$ (s, 3H, C(4")$\left.\mathrm{CH}_{3}\right), 3.57\left(\mathrm{~m}, 1 \mathrm{H}, \mathrm{H}-1^{\prime}\right), 4.42(\mathrm{q}, J=7.0 \mathrm{~Hz}, 2 \mathrm{H}$, $-\mathrm{OCH}_{2} \mathrm{CH}_{3}$ ), 7.38 (d, $J=8.4 \mathrm{~Hz}, 1 \mathrm{H}, \mathrm{H}-6$ "), 7.54 (d, $J=8.0$ Hz, 1H, H-5”), 7.84 (s, 1H, H-3”), 8.43 (s, 1H, H-6), 10.48 (s, $1 \mathrm{H}, \mathrm{CHO}) .{ }^{13} \mathrm{C} \mathrm{NMR}\left(125 \mathrm{MHz}, \mathrm{CDCl}_{3}\right) \delta 7.83\left(\mathrm{C}-2{ }^{\prime}+\right.$ C3'), $14.34\left(-\mathrm{OCH}_{2} \mathrm{CH}_{3}\right), 20.69\left(\mathrm{C}-\mathrm{CH}_{3}\right), 36.70\left(\mathrm{C}-1^{\prime}\right)$, $61.30\left(-\mathrm{OCH}_{2} \mathrm{CH}_{3}\right), 116.04(\mathrm{C}-5), 118.24$ (C-6"), 121.21 (C-3a), 126.25 (C-2”), 129.60 (C-3”), 131.46 (C-2), 136.65 (C-4”), 136.84 (C-5”), 141.99 (C-3), 145.88 (C-6), 149.58 (C-7a), 156.63 (C-1”), 164.49 (C-COOEt), 167.63 (C-4), $187.66(\mathrm{C}-\mathrm{CHO})$.

Ethyl 2-(4-Chloro-2-formylphenoxy)-7-cyclopropyl-3nitro-4-oxo-4,7-dihydrothieno[2,3-b] pyridine-5-carboxylate (3d). This compound was prepared from 1 (0.2 g, $0.6 \mathrm{mmol})$ and 2-hydroxy-5-chlorobenzaldehyde (2d) (0.16 $\mathrm{g}, 0.9 \mathrm{mmol}$ ) by following the general procedure and reaction conditions as described above. Reaction time $12 \mathrm{~h}$; yield $0.18 \mathrm{~g}(67 \%), \mathrm{mp} 202-205^{\circ} \mathrm{C}$. HRMS (ESI) $m / z$ [M+Na] calcd for $\mathrm{C}_{20} \mathrm{H}_{15} \mathrm{ClN}_{2} \mathrm{O}_{7} \mathrm{SNa}$ : 485.01807; found: 485.01986; $[\mathrm{M}+\mathrm{H}]$ calcd for $\mathrm{C}_{20} \mathrm{H}_{16} \mathrm{ClN}_{2} \mathrm{O}_{7} \mathrm{~S}$ : 463.03613; found: 463.03778. IR 1683, 1623, 1555, 1526, 1487, 1448, 1394, $1323,1245,1160,1136,1067,1030,934,866,832,797,721$,
$630 \mathrm{~cm}^{-1} .{ }^{1} \mathrm{H}$ NMR $\left(500 \mathrm{MHz}, \mathrm{CDCl}_{3}\right) \delta 1.18(\mathrm{~m}, 4 \mathrm{H})\left(\mathrm{H}_{2}-\right.$ $\left.2^{\prime}+\mathrm{H}_{2}-3^{\prime}\right)$, and $1.29\left(\mathrm{t}, \mathrm{J}=7.0 \mathrm{~Hz}, 3 \mathrm{H}, \mathrm{CH}_{3} \mathrm{CH}_{2} \mathrm{O}-\right), 3.45(\mathrm{~m}$, $\left.1 \mathrm{H}, \mathrm{H}-1^{\prime}\right), 4.25$ (q, J=6.8 Hz, $\left.2 \mathrm{H},-\mathrm{OCH}_{2} \mathrm{CH}_{3}\right), 7.20$ (d, $J=$ $8.4 \mathrm{~Hz}, 1 \mathrm{H}, \mathrm{H}-6$ ”), 7.53 (dd, $J_{1}=2.4 \mathrm{~Hz}, J_{2}=8.8 \mathrm{~Hz}, 1 \mathrm{H}$, H-5”), 7.83 (d, J=2.4 Hz, 1H, H-3"), 8.28 (s, 1H, H-6), 10.31 (s, $1 \mathrm{H}, \mathrm{CHO}) .{ }^{13} \mathrm{C} \mathrm{NMR}\left(100 \mathrm{MHz}, \mathrm{CDCl}_{3}\right) \delta 7.92\left(\mathrm{C}-2{ }^{\prime}+\right.$ C3'), $14.35\left(-\mathrm{OCH}_{2} \mathrm{CH}_{3}\right), 36.79\left(\mathrm{C}-1^{\prime}\right), 61.41\left(-\mathrm{OCH}_{2} \mathrm{CH}_{3}\right)$, 116.12 (C-5), 119.21 (C-6"), 121.04 (C-3a), 127.16 (C-2”), 128.99 (C-3”), 132.11 (C-4"), 132.59 (C-2), 135.89 (C-5”), 142.61 (C-3), 146.12 (C-6), 147.76 (C-7a), 157.06 (C-1"), 164.37 (C-COOEt), 167.67 (C-4), 186.22 (C-CHO).

Ethyl 7-Cyclopropyl-3-nitro-4-oxo-2-(phenylthio)-4,7dihydrothieno[2,3-b]pyridine-5-carboxylate (3e). This compound was prepared from $1(0.2 \mathrm{~g}, 0.6 \mathrm{mmol})$ and thiophenol (2e) (0.07 g, $0.65 \mathrm{mmol})$ by following the general procedure and reaction conditions as described above. Reaction time $12 \mathrm{~h}$; yield $0.12 \mathrm{~g}$ (50\%), mp 208-209 ${ }^{\circ} \mathrm{C}$. HRMS (ESI) $m / z[\mathrm{M}+\mathrm{Na}]$ calcd for $\mathrm{C}_{19} \mathrm{H}_{16} \mathrm{~N}_{2} \mathrm{O}_{5} \mathrm{~S}_{2} \mathrm{Na}$ : 439.03928; found: 439.03896. IR 3900, 3089, 2952, 1728, $1688,1615,1559,1486,1453,1395,1344,1320,1229,1199$, 1146, 1070, 1044, 922, 875, 836, 800, 761, 694, 597, 554 $\mathrm{cm}^{-1} .{ }^{1} \mathrm{H}$ NMR $\left(500 \mathrm{MHz}, \mathrm{CDCl}_{3}\right) \delta 1.15-1.22(\mathrm{~m}, 4 \mathrm{H}$, $\left.\mathrm{H}_{2}-2^{\prime}+\mathrm{H}_{2}-3^{\prime}\right)$, and $1.33\left(\mathrm{t}, J=7.0 \mathrm{~Hz}, 3 \mathrm{H}, \mathrm{CH}_{3} \mathrm{CH}_{2} \mathrm{O}-\right)$, $3.41\left(\mathrm{~m}, 1 \mathrm{H}, \mathrm{H}-1^{\prime}\right), 4.29$ (q, $\left.J=7.0 \mathrm{~Hz}, 2 \mathrm{H},-\mathrm{OCH}_{2} \mathrm{CH}_{3}\right)$, 7.36 (m, 3H, H-2" + H-6" + H-4"), 7.49 (m, 2H, H-3" + H-5”), 8.26 (s, 1H, H-6). $\left.{ }^{13} \mathrm{C} \mathrm{NMR} \mathrm{(125} \mathrm{MHz,} \mathrm{CDCl}_{3}\right) \delta$ $7.78\left(\mathrm{C}-2\right.$ ' + C3'), $14.35\left(-\mathrm{OCH}_{2} \mathrm{CH}_{3}\right), 36.05\left(\mathrm{C}-1^{\prime}\right), 61.34$ $\left(-\mathrm{OCH}_{2} \mathrm{CH}_{3}\right), 116.00$ (C-5), 129.31 (C-4”), $129.64(\mathrm{C}-2 "+$ C-6”), 121.43 (C-3a), 132.45 (C-3" + C-5”), 130.39 (C-2), 141.39 (C-3), 145.42 (C-6), 150.81 (C-7a), 157.16 (C-1"), 164.81 (C-COOEt), 167.76 (C-4).

\section{4 Resazurin Reduction Assay}

The cytotoxic effects of compounds on drug-sensitive leukemia CCRF-CEM and multidrug-resistant P-glycoprotein-overexpressing CEM/ADR5000 cells were evaluated by the resazurin assay as previously described. ${ }^{29-33}$ All compounds were first tested at a single concentration of $10 \mu \mathrm{M}$ (Figure 2) against CCRF-CEM and CEM/ADR5000 cells. Compounds $\mathbf{3 a}, \mathbf{3 e}$, and $\mathbf{3 b}$, which significantly inhibited cell viability (reduction to less than $10 \%$ growth) were further tested in a concentration range from 0.001 to $10 \mu \mathrm{M}$ to determine the $50 \%$ inhibitory concentrations (for $\mathrm{IC}_{50}$ ) in both, CCRF-CEM and CEM/ ADR5000 cell lines. The fluorescence was measured using an Infinite M2000 Pro ${ }^{\mathrm{TM}}$ plate reader (Tecan, Crailsheim, Germany) at an excitation wavelength of $544 \mathrm{~nm}$ and an emission wavelength of $590 \mathrm{~nm}$. All experiments were performed three times with every six parallel measurements. The viability was evaluated based on a comparison with untreated cells. The $\mathrm{IC}_{50}$ values represent the concentrations of the compounds required to inhibit $50 \%$ of cell viability and were determined from a calibration curve by linear regression using Microsoft Excel. 


\section{Conclusion}

A series of novel thieno[2,3-b]pyridine derivatives have been synthesized and screened for their in vitro cytotoxicity towards sensitive CCRF-CEM and multidrug resistance CEM/ADR5000 leukemia cells. Compounds 3a, $\mathbf{3 b}$, and $\mathbf{3 e}$ inhibited the growth of both cell lines incorporating phenol without substitution at para position, which can be considered as lead structures for further drug development.

\section{Acknowledgments}

We gratefully thank the Deanship of Scientific Research at Mutah University, Al-Karak, Jordan for financial support. Also, the support of Prof. Dr. Thomas Efferth from Department of Pharmaceutical Biology, Institute of Pharmaceutical and Biomedical Sciences, Johannes Gutenberg University, Mainz, Germany in providing laboratory equipment for the biological assay and measurements is greatly acknowledged.

\section{Appendix A. Supplementary Material}

Supplementary data to this article includes ${ }^{1} \mathrm{H},{ }^{13} \mathrm{C}$, DEPT, 2D NMR and HRMS spectra of the synthesized ethyl 2-(aryloxo/arylthio)-7-cyclopropyl-3-nitro-4-oxo-4,7dihydrothieno[2,3-b]pyridine-5-carboxylate $3 \mathbf{a}-\mathbf{e}$ compounds which are described in this article.

\section{References}

1. V. P. Litvinov, V. V. Dotsenko, S. G. Krivokolysko, Russ. Chem. Bull. 2005, 54, 864-904. DOI:10.1007/s11172-005-0333-1

2. A. E. Mekky, S. M. Sanad, A. Y. Said, M. A. Elneairy, Synth. Commun. 2020, 50, 2376-2389.

DOI:10.1080/00397911.2020.1778033

3. R. M. Kumbhare, T. L. Dadmal, R. Pamanji, U. B. Kosurkar, L. R. Velatooru, K. Appalanaidu, Y. K. Rao, J. V. Rao, Med. Chem. Res. 2014, 23, 4404-4413.

DOI:10.1007/s00044-014-1006-0

4. F. M. Shaikh, N. B. Patel, G. Sanna, B. Busonera, P. La Colla, D. P. Rajani, Med. Chem. Res. 2015, 24, 3129-3142.

DOI:10.1007/s00044-015-1358-0

5. M. Singh, S. K. Singh, M. Gangwar, G. Nath, S. K. Singh, Med. Chem. Res. 2016, 25, 263-282. DOI:10.1007/s00044-015-1479-5

6. M. Bhat, S. L. Belagali, Res. Chem. Intermediat. 2016, 42, 6195-6208. DOI:10.1007/s11164-016-2454-6

7. C. Kharbanda, M. S. Alam, H. Hamid, K. Javed, S. Bano, A. Dhulap, Y. Ali, S. Nazreen, S. Haider, Bioorg. Med. Chem. 2014, 22, 5804-5812. DOI:10.1016/J.BMC.2014.09.028

8. T. I. Chaban, V. V. Ogurtsov, V. S. Matiychuk, I. G. Chaban, I. L. Demchuk, I. A. Nektegayev, Acta Chim. Slov. 2019, 66, 103-111. DOI:10.17344/acsi.2018.4570
9. T. I. Chaban, J. E. Matiychuk, O. Y. Shyyka, I. G. Chaban, V. V. Ogurtsov, I. A. Nektegayev, V. S. Matiychuk, Acta Chim. Slov. 2020, 67, 1035-1043. DOI:10.17344/acsi.2019.5439

10. S. S. Thakkar, P. Thakor, A. Ray, H. Doshi, V. R. Thakkar, Bioorg. Med. Chem. 2017, 25, 5396-5406.

DOI:10.1016/j.bmc.2017.07.057

11. M. M. El-Abadelah, S. S. Sabri, H. A. Al-Ashqar, Heterocycles 1997, 2, 255-264. DOI:10.3987/COM-96-7613

12. M. E. Abdelaziz, M. M. El-Miligy, S. M. Fahmy, M. A. Mahran, A. A. Hazzaa, Bioorg. Chem. 2018, 80, 674-692. DOI:10.1016/J.BIOORG.2018.07.024

13. C. Eurtivong, I. Reynisdóttir, S. Kuczma, D. P. Furkert, M. A. Brimble, J. Reynisson, Bioorg. Med. Chem. 2016, 24, 35213526. DOI:10.1016/J.BMC.2016.05.061

14. J. M. Hung, H. J. Arabshahi, E. Leung, J. Reynisson, D. Barker, Eur. J. Med. Chem. 2014, 86, 420-437.

DOI:10.1016/j.ejmech.2014.09.001

15. S. Singh, B. Sharma, S. S. Kanwar, A. Kumar, Front. Plant Sci. 2016, 7, 1667. DOI:10.3389/fpls.2016.01667

16. M. M. Gottesman, T. Fojo, S. E. Bates, Nat. Rev. Cancer. 2002, 2, 48-58. DOI:10.1038/nrc706

17. T. Efferth, M. Volm, Arch. Toxicol. 2017, 91, 2515-2538. DOI:10.1007/s00204-017-1938-5

18. N. Erin, J. Grahovac, A. Brozovic, T. Efferth, Drug Resist. Update 2020, 53, 100715. DOI:10.1016/j.drup.2020.100715

19. C. H. Choi, Cancer Cell Int. 2005, 5, 30. DOI:10.1186/1475-2867-5-30

20. T. Efferth, Curr. Mol. Med. 2001, 1, 45-65. DOI: $10.2174 / 1566524013364194$

21. J. P. Gillet, T. Efferth, D. Steinbach, J. Hamels, F. De Longueville, V. Bertholet, J. Remacle, Cancer Res. 2004, 64, 89878993. DOI:10.1158/0008-5472.CAN-04-1978

22. X. X. Zeng, R. L. Zheng, T. Zhou, H. Y. He, J. Y. Liu, Y. Zheng, A. P. Tong, M. L. Xiang, X. R. Song, S. Y. Yang, L. T. Yu, Bioorg. Med. Chem. Lett. 2010, 20, 6282-6285.

DOI:10.1016/j.bmcl.2010.08.088

23. R. Zhou, W. J. Huang, Z. Y. Guo, L. Li, X. R. Zeng, Y. Q. Deng, F. Y. Hu, A. P. Tong, L. Yang, J. L. Yang, Oncol. Rep. 2012, 28, 225-231. DOI:10.3892/or.2012.1776

24. S. A. Al-Trawneh, M. M. El-Abadelah, J. A. Zahra, S. A. Al-Taweel, F. Zani, M. Incerti, A. Cavazzoni, P. Vicini, Bioorg. Med. Chem. 2011, 19, 2541-2548.

DOI:10.1016/j.bmc.2011.03.018

25. S. A. Al-Trawneh, S. A. Al-Dawdieh, N. S. Abutaleb, A. H. Tarawneh, E. A. Salama, M. M. El-Abadelah, M. N. Seleem, Chem. Pap. 2020, 74, 1241-1252.

DOI:10.1007/s11696-019-00974-9

26. A. H. Tarawneh, F. León, S. K. Jain, A. V. Gadetskaya, S. T. Abu-Orabi, B. L. Tekwani, S. J. Cutler, Med. Chem. Res. 2018, 27, 1269-1275. DOI:10.1007/s00044-018-2146-4

27. A. H Tarawneh, F. León, S. Pettaway, K. M. Elokely, M. L. Klein, J. Lambert, A. Mansoor, S. J. Cutler, J. Nat. Prod. 2015, 78, 1461-1465. DOI:10.1021/acs.jnatprod.5b00218

28. T. Efferth, V. B. Konkimalla, Y. F. Wang, A. Sauerbrey, S. Meinhardt, F. Zintl, J. Mattern, M. Volm, Clin. Cancer Res. 2008, 14, 2405-2412. DOI:10.1158/1078-0432.CCR-07-4525 
29. J. O’Brien, I. Wilson, T. Orton, F. Pognan, Eur. J. Biochem. 2000, 267, 5421-5426.

DOI:10.1046/j.1432-1327.2000.01606.x

30. S. Abdelfatah, M. Böckers, M. Asensio, O. Kadioglu, A. Klinger, E. Fleischer, T. Efferth, Phytomedicine 2020, 153196. DOI:10.1016/j.phymed.2020.153196

31. N. Mahmoud, M. E. M. Saeed, Y. Sugimoto, A. Klinger, E. Fleischer, T. Efferth, Phytomedicine 2020, 77, 153271.

DOI:10.1016/j.phymed.2020.153271
32. A. T. Mbaveng, G. F. Chi, I. N. Bonsou, S. Abdelfatah, A. N. Tamfu, E. M. O. Yeboah, V. Kuete, T. Efferth, Phytomedicine 2020, 76, 153261. DOI: 10.1016/j.phymed.2020.153261

33. G. Yan, M. Dawood, M. Böckers, S. M. Klauck, C. Fottner, M. M. Weber, T. Efferth, Phytomedicine 2020, 79, 153332. DOI:10.1016/j.phymed.2020.153261

\section{Povzetek}

Iz ključnega intermediata etil 7-ciklopropil-2-kloro-3-nitro-4-okso-4,7-dihidrotieno[2,3-b]piridin-5-karboksilata (1) smo s substitucijo 2-klorovega substituenta $\mathrm{z}$ anioni, pripravljenimi iz fenola (2a), salicilaldehidnih derivatov $\mathbf{2 b}-\mathbf{d}$ in tiofenola (2e), sintetizirali serijo novih substituiranih 7-ciklopropil-2-(2-arilokso)-3-nitro-4-okso-4,7-dihidrotieno[2,3-b] piridin-5-karboksilatov 3a-e. Za nove spojine smo določili in vitro citotoksično delovanje proti občutljivim CCRF-CEM levkemičnim celicam in proti CEM/ADR5000 levkemičnim celicam, odpornim na več različnih učinkovin. Testiranje je pokazalo, da so spojine $\mathbf{3 a}$, $\mathbf{3 b}$ in $3 \mathbf{e}$ inhibirale obe celični liniji. Spojina $\mathbf{3 b}$, ki vsebuje fenolni fragment, pa je pokazala največjo inhibitorno aktivnost rasti pri celicah CEM/ADR5000 in CCRF-CEM z IC ${ }_{50}$ vrednostmi $4.486 \pm 0.286 \mu \mathrm{M}$ (za prvo celično linijo) in $2.580 \pm 0.550 \mu \mathrm{M}$ (za drugo celično linijo). Skupno gledano rezultati kažejo, da pripravljeni tieno[2,3-b]piridini izkazujejo potencialno uporabnosti kot protirakave učinkovine in da si zato zaslužijo, da so predmet nadaljnjih raziskav. 